OPEN ACCESS

Edited by:

Asma Amleh,

American University in Cairo, Egypt

Reviewed by:

Jafar Sharif,

RIKEN Center for Integrative Medical

Sciences (IMS), Japan

Carmen Jeronimo,

Portuguese Oncology Institute,

Portugal

*Correspondence:

César López-Camarillo

genomicas@yahoo.com.mx

Specialty section:

This article was submitted to

Epigenomics and Epigenetics,

a section of the journal

Frontiers in Genetics

Received: 23 September 2018 Accepted: 28 January 2019

Published: 01 March 2019

Citation:

Carlos-Reyes Á,

López-González JS,

Meneses-Flores M,

Gallardo-Rincón D, Ruíz-García E, Marchat LA, Astudillo-de la Vega $H$,

Hernández de la Cruz ON and

López-Camarillo C (2019) Dietary

Compounds as Epigenetic

Modulating Agents in Cancer.

Front. Genet. 10:79.

doi: 10.3389/fgene.2019.00079

\section{Dietary Compounds as Epigenetic Modulating Agents in Cancer}

\author{
Ángeles Carlos-Reyes ${ }^{1}$, José Sullivan López-González ${ }^{1}$, Manuel Meneses-Flores', \\ Dolores Gallardo-Rincón ${ }^{2}$, Erika Ruíz-García ${ }^{2}$, Laurence A. Marchat ${ }^{3}$, \\ Horacio Astudillo-de la Vega ${ }^{4}$, Olga N. Hernández de la Cruz ${ }^{5}$ and \\ César López-Camarillo ${ }^{5 *}$
}

\begin{abstract}
'Laboratorio de Cáncer de Pulmón, Instituto Nacional de Enfermedades Respiratorias "Ismael Cosio Villegas", Mexico City, Mexico, ${ }^{2}$ Laboratorio de Medicina Traslacional, Instituto Nacional de Cancerología, Mexico City, Mexico, ${ }^{3}$ Programa en Biomedicina Molecular y Red de Biotecnología, Instituto Politécnico Nacional, Mexico City, Mexico, ${ }^{4}$ Laboratorio de Investigación Traslacional en Cáncer y Terapia Celular, Hospital de Oncología, Centro Médico Nacional Siglo XXI, Instituto Mexicano del Seguro Social, Mexico City, Mexico, ${ }^{5}$ Posgrado en Ciencias Genómicas, Universidad Autónoma de la Ciudad de México, Mexico City, Mexico
\end{abstract}

Epigenetic mechanisms control gene expression during normal development and their aberrant regulation may lead to human diseases including cancer. Natural phytochemicals can largely modulate mammalian epigenome through regulation of mechanisms and proteins responsible for chromatin remodeling. Phytochemicals are mainly contained in fruits, seeds, and vegetables as well as in foods supplements. These compounds act as powerful cellular antioxidants and anti-carcinogens agents. Several dietary compounds such as catechins, curcumin, genistein, quercetin and resveratrol, among others, exhibit potent anti-tumor activities through the reversion of epigenetic alterations associated to oncogenes activation and inactivation of tumor suppressor genes. In this review, we summarized the actual knowledge about the role of dietary phytochemicals in the restoration of aberrant epigenetic alterations found in cancer cells with a particular focus on DNA methylation and histone modifications. Furthermore, we discussed the mechanisms by which these natural compounds modulate gene expression at epigenetic level and described their molecular targets in diverse types of cancer. Modulation of epigenetic activities by phytochemicals will allow the discovery of novel biomarkers for cancer prevention, and highlights its potential as an alternative therapeutic approach in cancer.

Keywords: phytochemicals, cancer therapy, histones modifications, epigenetic machinery, DNA methylation

\section{INTRODUCTION}

The knowledge of epigenetic mechanisms regulating gene expression has allowed significant advances in the understanding of cancer biology. Cancer is caused by the accumulation of genetic and epigenetic alterations, which induce alterations in the expression of oncogenes and tumor suppressor genes (Sharma et al., 2010; McCleary-Wheeler et al., 2013; Aggarwal et al., 2015). Changes in the DNA sequence are caused by mutations, amplifications or deletions. Moreover, regulation of gene expression is also modulated by epigenetics modifications of chromatin with no alterations in DNA sequence. The main epigenetic mechanisms studied in mammalian cells are DNA methylation and histones modifications which induce remodeling of chromatin resulting in 
changes of cellular phenotypes (Shukla et al., 2014). In cancer cells, diverse epigenetic alterations of cancer-related genes occur in the early stages of tumor development. Remarkably, these epigenetic modifications of chromatin are inherited and reversible, so they represent promising targets for the development of novel drugs targeting the epigenome which may contribute to amelioration of conventional therapies in cancer (Esteller, 2008; Shukla et al., 2014; Kagohara et al., 2017; Zadi Heydarabad et al., 2018). Improvement in patient's survival is the result of the use new therapeutic drugs and personalized options. Some of these treatments have been combined with alternative therapies represented by natural phytochemical compounds. It has been reported that a diet rich in vegetables and fruits can significantly reduce the risk of cancer development, due to the action of phytochemicals which may regulate the expression of oncogenes and tumor suppressor genes. Remarkably, phytochemicals may act through epigenetic mechanisms such as modulation of DNA methyltransferases (DNMTs) and histone deacetylases (HDACs) activities (Yang and Zheng, 2014; Zhou et al., 2016). In general, cancer treatments involve the use of chemo-radio therapeutic agents, kinase inhibitors, personalized antibodies as well as compounds that stimulate the immune system. In particular, HDAC inhibitors and demethylating drugs modified gene expressions by reversing the aberrant epigenetic alterations acquired during tumorigenesis (Luczak and Jagodziński, 2006). In this context, phytochemicals may represent an alternative therapeutic option for cancer treatment. In this review, we first provided an overview of the most frequent epigenetic alterations in human cancers, then we described the most studied dietary phytochemicals and their potential use in the reversion of cancer hallmarks through epigenetic mechanisms, and finally we discussed their potential use as an alternative strategy for cancer therapy.

\section{EPIGENETIC MECHANISMS}

\section{DNA Methylation}

DNA methylation is a normal mechanism of gene silencing by transcriptional repression. Global DNA methylation is associated with several processes such as genomic imprinting, $\mathrm{X}$-chromosome inactivation, and the repression of repeated elements. Importantly, dysregulation of these cellular events is frequently found during early and late stages of tumorigenesis (Lim and Maher, 2010; Jin et al., 2011). DNA methylation involves the covalent modification of DNA mediated by DNMT, which transfer methyl groups (-CH3) from $S$-adenosyl-Lmethionine (SAM) to cytosine in the so-called CpG islands (Verma and Srivastava, 2002). The CpG regions are contained in large DNA sequences found mainly in gene promoters, intergenic regions and repeated elements (Esteller, 2011; Moore et al., 2013). Aberrant DNA methylation patterns play a crucial role in genomic instability, activation of oncogenes and silencing of tumor suppressor genes involved in cell proliferation, cell cycle, DNA repair, stress response and apoptosis (Esteller, 2005; Ehrlich, 2009; Berdasco and Esteller, 2010; Zaidi et al., 2013; Li et al., 2017a). These alterations are common during the development and progression of carcinogenesis (Esteller and Herman, 2002). Several studies have showed the impact of hypomethylation or hypermethylation of DNA sequences associated with the transcriptional regulation of cancer-related genes (Mossman and Scott, 2006). For instance, LINE-1 gene hypomethylation is associated with different clinical-pathological characteristics in lung cancer; early carcinogenesis in breast cancer, and metastasis in colorectal adenocarcinoma (Estécio et al., 2007; Hur et al., 2014; Park et al., 2014; Imperatori et al., 2017). On the other hand, hypomethylation of specific genes like TTF-3, MUC4, and CT45 frequently occur in prostate, pancreatic and ovarian cancers (Zhu et al., 2011; Zhang W. et al., 2015; Haldrup et al., 2017; Nørgaard et al., 2017). The hypermethylation of RASSF1A gene has been identified as a diagnostic marker in lung cancer, whereas it contributes to increased mortality in women with breast cancer. Hypermethylation of RASSF1A also has been related with high risk of ovarian cancer (El-Sherif et al., 2016; Rezk et al., 2018; Yadav et al., 2018). Other studies showed that hypermethylation of PDE3A gene modulated the response to therapy in cisplatin-resistant non-small cell lung cancer (NSCLC) (Tian et al., 2017). In addition, hypermethylation of genes such as NDN activated the WNT signaling pathway contributing to cell proliferation of colorectal cancer cells (Hu et al., 2017). These examples illustrate the impact of alterations in epigenetic mechanisms in the development of diverse types of human cancers.

\section{Histone Modifications}

Histones are alkaline proteins located in the nucleus of eukaryotic cells (Li, 2012). Their function is to package DNA into structural units called nucleosomes. The core component of nucleosome is the histone octamer, which is formed by two copies of each histone $\mathrm{H} 2 \mathrm{~A}, \mathrm{H} 2 \mathrm{~B}, \mathrm{H} 3$; whereas histone $\mathrm{H} 1$ binds to the linker DNA between nucleosomes (Cutter and Hayes, 2015; Biterge, 2016). The histones have flexible tails that protrude from the lateral surface of the nucleosome. These tails are susceptible to suffer different chemical modifications in the lysine $(\mathrm{K})$, serine $(\mathrm{S})$, threonine $(\mathrm{T})$ and arginine (R) amino acids (Smith and Denu, 2009; Lawrence et al., 2016). Histone modifications in specific amino acids residues (termed histone code) modulate the chromatin structure and gene expression (Karlić et al., 2010; Prakash and Fournier, 2017). Histone proteins have structural and functional roles in the transition between the active and inactive chromatin states. When chromatin is highly packed (heterochromatin) the transcription of genes is blocked; whereas when the chromatin is less condensed (euchromatin) the transcription is activated (Mariño-Ramírez et al., 2005; Bégin and Nadeau, 2014; Glant et al., 2014; Biterge, 2016). Histones can be modified covalently in the $\mathrm{N}$ - and C-terminal tails by two families of enzymes; the histone acetyltransferases (HATs) that transfer acetyl groups from coenzyme A (CoA), and the histone deacetylases (HDACs) that remove the acetyl groups from specific amino acid residues (Bannister and Kouzarides, 2011). Histone modifications regulate different biological processes such as transcription, chromosome packaging, and DNA damage 
response and repair. The primary modifications of histones are acetylation, methylation, phosphorylation, ubiquitination, sumoylation, glycosylation and poly ADP ribosylation (Li, 2012; Marmorstein and Zhou, 2014; Zhang T. et al., 2015; Shanmugam et al., 2018). The acetylation and methylation are well studied mechanisms of histone modifications, and they are key regulators of cellular proliferation, differentiation, division and plasticity (Cohen et al., 2011).

In cancer cells, histones modifications at specific amino acids residues are related to transcription activation or repression. In most species, histone $\mathrm{H} 3$ is primarily acetylated at lysines $9,14,18,23$, and 56, methylated at arginine 2 and lysines 4, $9,27,36$, and 79, and phosphorylated at ser10, ser28, Thr3, and Thr11. For instance, gene activation has been associated with trimethylation of lysine 4 on the histone $\mathrm{H} 3$ (H3K4me3), acetylation of lysine 9 on the histone $\mathrm{H} 3$ (H3K9ac) and monomethylation of lysine 20 on the histone H3 (H3K20me). In contrast, the H3K9me3 and H3K27 epigenetic marks induce repression of gene expression (Leszinski et al., 2012; Bag and Bag, 2018). In prostate cancer, $\mathrm{H} 3 \mathrm{~K} 9 \mathrm{me} 2$ and $\mathrm{H} 3 \mathrm{Ac}$ marks distinguish between tumors from non-malignant tissues, and the H3K4me1 modification was established as a biomarker of tumor progression and a predictor of recurrence after radical prostatectomy (Ellinger et al., 2009). H3K4me and H3K9 modifications were regulated by histone demethylase JMJD2B and promoted hormonal responsiveness in breast cancer patients (Shi et al., 2011). In early-stage of colon cancer (TNM stage I and II) low nuclear expression of $\mathrm{H} 3 \mathrm{~K} 4 \mathrm{me} 3$ and high expression of $\mathrm{H} 3 \mathrm{~K} 9 \mathrm{me} 3$ and H4K20me3 were associated with good prognosis (Benard et al., 2014).

\section{POLYPHENOLS CLASSIFICATION AND FUNCTIONS}

Polyphenols are the most important group of phytochemicals present in plants. They are secondary plant metabolites found in the fruits, vegetables, cereals, and natural beverages. These compounds exhibit biological roles in human cells acting as antioxidants, antimicrobials, detoxification, immune system stimulation, decrease of platelets aggregation, modulation of hormonal metabolism and anti-tumoral agents (Tsao, 2010; Saxena et al., 2013; Jabeena et al., 2014; Ganesan and $\mathrm{Xu}, 2017)$. Research in recent years strongly supports a role for polyphenols as important molecules protecting cells from DNA damage (Choudhury et al., 2009; Saxena et al., 2013). Therefore, polyphenols have important benefits in the prevention and treatment of oncologic diseases. Currently, the main polyphenols studied in cancer cells are the phenolic acids, flavonoids, stilbenes, and lignans (Figure 1) (Choudhury et al., 2009; Tsao, 2010; Ganesan and $\mathrm{Xu}, 2017)$.

\section{Phenolic Acids}

The hydroxycinnamic acids are the more frequent simple phenolic compounds found in natural sources. The cinnamic acid, $p$-coumaric acid, ferulic acid, caffeic acid, chlorgenic acid, and rosmarinic acid belong to this class. These acids are rarely found as free form but these compounds can found as glycosylated derivatives or esters of quinic acid, shikimic acid, and tartaric acid in processed food that has undergone freezing, sterilization, or fermentation. High concentrations of hydroxybenzoic acid are contained in red fruits, black radish, and onions. Hydroxybenzoic acids form complex structures such as hydrolysable tannins. These tannins also have multiple health benefits including cancer suppression (Tsao, 2010; Hardman, 2014). Combination of caffeic and quinic acid form the chlorogenic acid, which is found in many types of fruit as blueberries, kiwis, plums, cherries, and at high concentrations in coffee. The curcumin acts as antioxidant and anti-inflammatory and has been reported that it has multiple effects in cancer cells (Manach et al., 2004; Hardman, 2014).

\section{Flavonoids}

Flavonoids are natural molecules containing variable phenolic structures composed of 15-carbon (C6-C3-C6) skeleton and two benzene rings joined by a linear 3-carbon chain (El Gharras, 2009). Subgroups of flavonoids are: flavonols such as quercetin, kaempferol, and myricetin. They are found in onions, curly, broccoli, and blueberries. The flavanones as eriodictyol, hesperetin, and naringenin are found in grapefruit, oranges, and lemons. The isoflavonoids including daidzein, genistein, and glycitein are presents in leguminous. The flavones as apigenin and luteolin are in cereals. The flavanols as catechin are found in green tea and chocolate, and the anthocyanins including cyanidin, delphinidin, malvidin, pelargonidin, peonidin, and petunidin are present in berries, pears, apples, grapes and peaches (Kawser Hossain et al., 2016). The biological effects of flavonoids have been linked to their anti-obesity, anti-diabetic and anti-oxidative activities. In cancer, these compounds inhibit cell proliferation, induce cytotoxicity, suppression of angiogenesis; and cause cell death by apoptosis (Figure 2) (Chahar et al., 2011; Falcone Ferreyra et al., 2012).

\section{Stilbenes}

Natural stilbenes are non-flavonoid phytochemicals with polyphenolic structure that containing a 1,2-diphenylethylene nucleus. Stilbenes are found in berries, grapes and peanuts. These compounds have a high potential for the prevention and treatment of different diseases. In cancer cells, they showed antioxidant and anti-inflammatory effects, as well as cell death induction. The main stilbene studied to date in cancer is resveratrol (Niesen et al., 2013; Sirerol et al., 2016).

\section{Sulforaphane}

Sulforaphane [1-isothiocyanato-4-(methyl-sulfinyl)] butane is the most widely characterized molecule belong to the isothiocyanate group of organosulfur compounds. Sulforaphane (SFN) is produced by the hydrolysis of glucoraphanin after intake of cruciferous vegetables such as broccoli, cabbages, kale, Brussels sprouts, radish, and mustard. This compound displays anti-inflammatory, antibiotic, and antioxidant activities (Figure 2). In cancer cells, SFN acts 


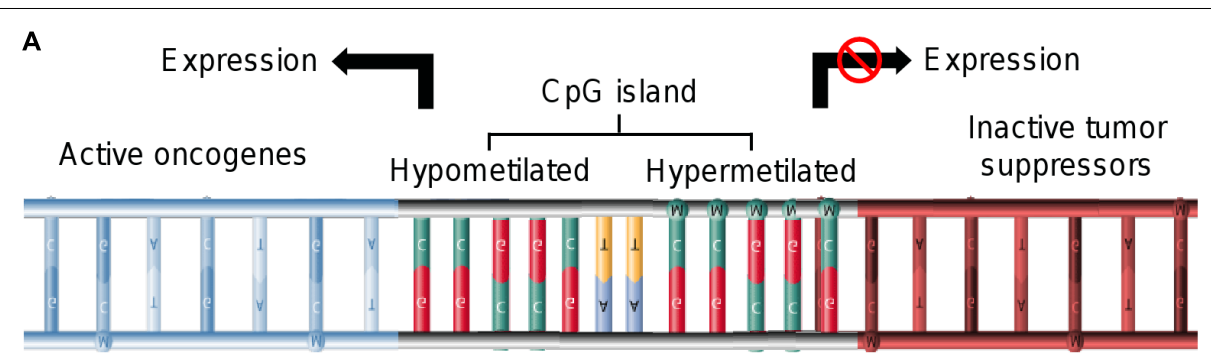

Promoter regions

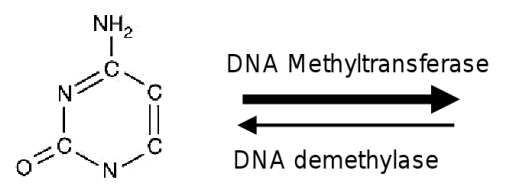

Cytosine<smiles>Cc1c[nH]c(=O)nc1N</smiles>

5-methyl Cytosine

B

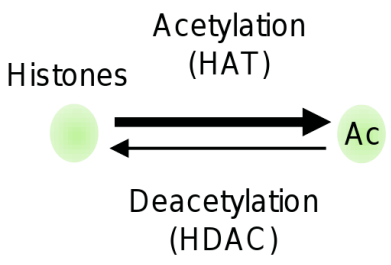

FIGURE 1 | Epigenetic alterations in cancer. (A) Methylation of DNA by DNA methyltransferases occurs on CpG islands of promoter gene regions. Hypermethylation of DNA induces repression of gene expression, whereas the hypomethylation status is associated to activation of gene transcription. (B) Histone modifications include acetylation by HAT and deacetylation by HDAC. Acetylated status of histones is observed in euchromatin and related to oncogenes activation. Histone methylation can be associated with either transcriptional repression or activation. Trimethylation of histone $\mathrm{H} 3$ at lysine 4 (H3K4me3) is an active mark for transcription.

as potent chemopreventive and anti-tumoral natural agent (Joozdani et al., 2015; Tortorella et al., 2015).

\section{EPIGENETIC MODULATION BY POLYPHENOLS IN CANCER PATHWAYS}

Recent reports indicate that dietary supplements and natural compounds may restore the normal epigenetic marks which are altered during carcinogenesis. The phytochemicals most studied in cancer are epigallocatechin-gallate (EGCG), quercetin, resveratrol, curcumin, and SFN. Several studies have showed that these natural compounds inhibit several cellular processes associated to cancer (Figure 3). In particular, these compounds blocked the development and progression of tumors by targeting key signaling transducers resulting in the restoration of tumor suppressor genes, and inhibition of oncogenes expression (Greenlee, 2012; Guo et al., 2015b; Zhou et al., 2016). These effects are mediated, in part, by the modulation of epigenetic machinery which included the regulation of DNMTs and HDACs activities (Figure 3 and Table 1) (Shukla et al., 2014; Thakur et al., 2014; Li et al., 2015; Deb and Gupta, 2015; Shankar et al., 2016; Sundaram et al., 2017).

\section{Epigenetic Modulation by EGCG in Cancer Cells}

Epigallocatechin-gallate is a polyphenolic catechin mainly found in green tea and its regular intake might significantly reduce the risk of breast and prostate cancer. This natural compound may induce apoptosis and inhibition of cell proliferation by epigenetic 


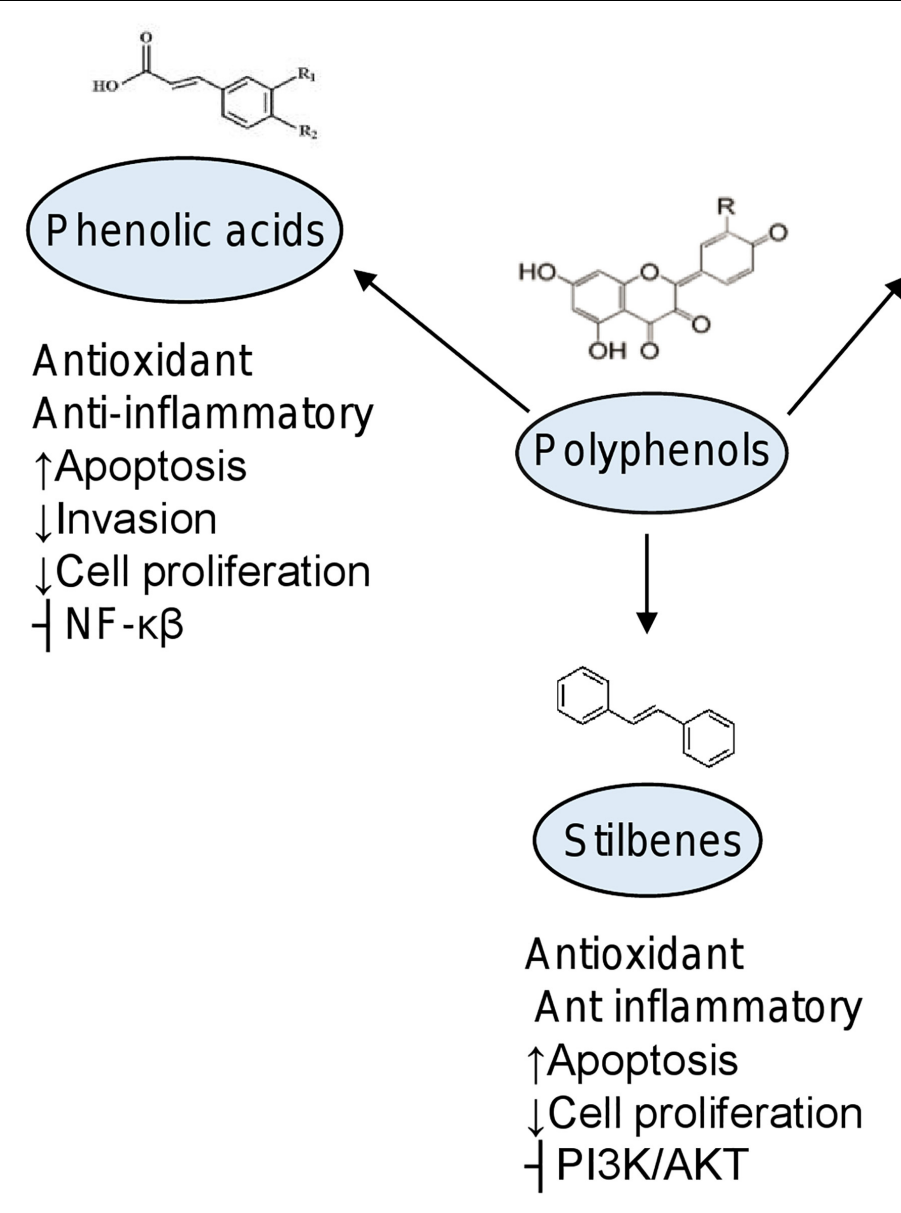

FIGURE 2 | Biological effects of phytochemicals in cancer. Chemical structures of subgroups of polyphenols and organosulfur compounds. Effects in diverse cellular processes are indicated. $\vdash$, inhibition; $\uparrow$, increased; $\downarrow$, decreased.

mechanisms (Greenlee, 2012; Shukla et al., 2014; Aggarwal et al., 2015). It has been reported that EGCG epigenetically reactivated p21/waf1, Bax and PUMA in prostate cancer cells, leading to cell cycle arrest and apoptosis mediated by proteasomal degradation of class I HDACs (Thakur et al., 2011). Studies of molecular modeling indicated that EGCG directly binds to the enzymatic substrates of DNMT3b and HDAC1 leading to their inhibition and reactivation of tumor suppressor genes such as retinoic acid receptor $\beta$, cadherin 1 and death-associated protein kinase- 1 (Khan et al., 2015).

Lee Y.H. et al. (2012) reported that EGCG repressed the hormone responsiveness of androgen receptor (AR) by reducing the acetylation of $\mathrm{AR}$, leading to decreased cell proliferation and promoting cell death in LNCaP prostate cancer cell line. Remarkably, EGCG is a potential epigenetic modifier of DNMTs and HDACs and restores epigenetically silenced genes in skin and cervical cancers. For instance, in skin cancer cells, EGCG significantly decreased the proteins levels of DNMT1, DNMT3a, and DNMT3b and modulated the HDAC activities allowing the transcriptional activation of tumor suppressor genes such as p16 INK4a and Cip1/p21. In esophageal cancer, EGCG induced apoptosis and inhibited cell growth of ECa109 cells through p16 gene demethylation (Nandakumar et al., 2011; Meng et al., 2017). Moreover, EGCG reactivated the expression of WIF1 (Wnt inhibitory factor-1) through promoter demethylation and inhibited cell growth by downregulating the Wnt canonical pathway in H460 and A549 lung cancer cell lines (Gao et al., 2009). The DNA hypomethylation as a consequence of 5-Azadc treatment has been shown to trigger the expression of prometastatic genes in prostate cancer. Pandey et al. (2010) showed that promoter demethylation and chromatin remodeling by green tea polyphenols leads to re-expression of GSTP1 in human prostate cancer cells.

During chemotherapy, EGCG sensitized the ER $\alpha$-negative cells to respond to $17 \beta$-estradiol and the antagonist tamoxifen. EGCG in combination with the HDAC inhibitor trichostatin A (TSA) reactivated the $\mathrm{ER} \alpha$ expression in triple negative MDA-MB-231 breast cancer cells by altering acetylation and methylation of histones and remodeling the chromatin structure. In addition, EGCG in combination with SFN sensitized the ER $\alpha$-negative breast cancer cells to tamoxifen treatment, thus inhibiting cell proliferation (Li et al., 2010, 2017b). These examples illustrate how combination of polyphenols with current cancer treatments has a great impact in the inhibition of cancer 


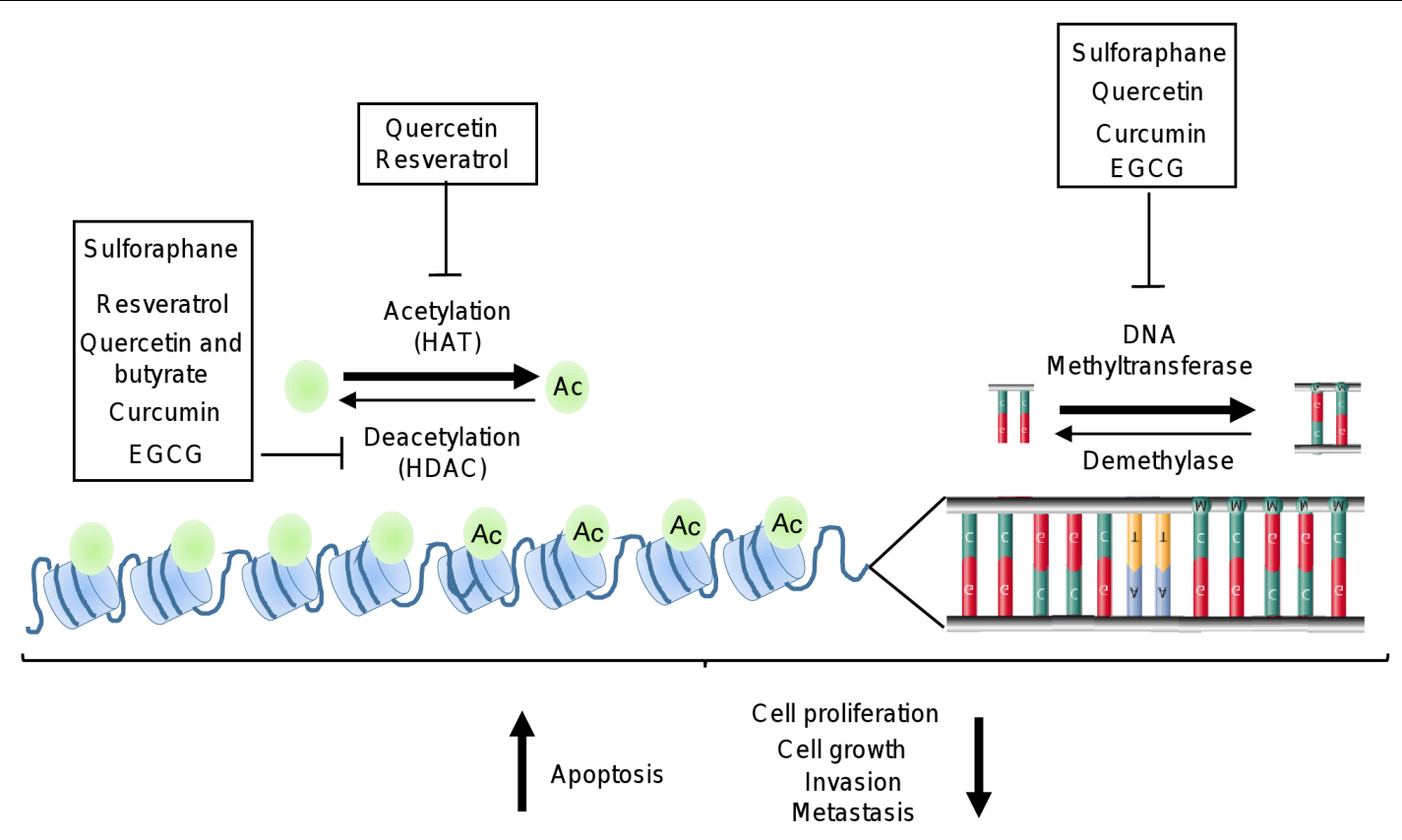

FIGURE 3 | Epigenetic machinery as targets of polyphenols. Illustration depicts how polyphenols may inhibit HDAC, HAT, and DNA methyltransferases activities which are deregulated in cancer cells.

hallmarks through epigenetic mechanisms suggesting clinical implications in patients therapies.

\section{Epigenetic Modulation by Curcumin in Cancer}

Curcumin is a phenolic component isolated from the roots of plant Curcuma longa (turmeric) widely used in China and India for medicinal purposes. Several studies indicate that curcumin has antioxidant, anti-inflammatory, antiproliferative, anti-angiogenic, and anti-cancer properties (Hewlings and Kalman, 2017; Kocaadam and Şanlier, 2017). Moreover, this natural compound has been considered as an excellent non-toxic hypomethylating agent for breast cancer therapy (Kumar et al., 2017). For instance, curcumin inhibited DNMT1 expression and restored the function of RASSF1A by promoter hypomethylation in estrogen positive MCF-7 breast cancer cell line. Furthermore, curcumin decreased the cell proliferation and breast tumors growth in vivo (Du et al., 2012). Curcumin and 5-aza-dc reactivated the RAR $\beta$ gene through promoter hypomethylation in $\mathrm{H} 460$ lung cancer cells. Moreover, when A549 lung cancer cells were implanted in nude mice and treated with curcumin, tumor growth was significantly decreased. This effect was mediated by increasing of RAR $\beta$ and decreasing of DNMT3b expression (Jiang et al., 2015). On the other hand, curcumin induced histone hypoacetylation and apoptosis associated to PARP activity in brain cancer cells. Also, curcumin impeded differentiation of astrocytes and promoted neural differentiation associated with hypoacetylation of $\mathrm{H} 3$ and H4. Other studies showed that curcumin increased protein levels of RANK in human glioblastoma cells through a demethylation mechanism. Curcumin-induced histone hypoacetylation enhanced caspase-3-dependent glioma cell death and neurogenesis of neural progenitor cells (Kang et al., 2006). Additionally, low levels of STAT3 caused RANK promoter demethylation inducing its reactivation (Wu et al., 2013).

In the acute myeloid leukemia (AML), curcumin downregulated the expression of DNMT1 in diverse cell lines in vivo and in ex vivo models. Curcumin blocks the positive regulators of DNMT1, p65 and Sp1 decreasing their activity for binding to the promoter region of DNMT1. Additionally, curcumin restored p15INK4b expression by hypomethylation of its promoter inducing cell cycle arrest at G1 phase and apoptosis in vitro (Yu et al., 2013). Importantly, in mice implanted with the MV4-11 cell line of AML, curcumin suppressed tumor growth (Yu et al., 2013).

In prostate cancer, curcumin inhibited tumor development in TRAMP mice model due to reversion of methylation status of Nrf2 promoter (Khor et al., 2011). Also, curcumin promoted apoptosis of LNCaP cells inhibiting JNK signaling and repressing H3K4me3 epigenetic mark. Combination of curcumin and JQ-1 efficiently suppresses prostate cancer development (Zhao et al., 2018). In HT29 colon cancer cells, curcumin inhibited the colony formation and decreased methylation of DLEC1 promoter associated to downregulation of DNMT1, DNMT3a, DNMT3b, and HDAC4/5/6/8 proteins (Guo et al., 2015a). On the other hand, Link et al. (2013) using a genome-wide approach showed that, in contrast to non-specific global hypomethylation induced by 5 -aza-CdR, curcumin induced specific changes in DNA methylation of a subset of genes involved in cell viability and proliferation in colorectal cancer cells. 
TABLE 1 | Epigenetic modulated targets by phytochemicals in cancer.

\begin{tabular}{|c|c|c|c|c|c|c|c|}
\hline $\begin{array}{l}\text { Phytochemical } \\
\text { group }\end{array}$ & Compound & $\begin{array}{l}\text { Natural } \\
\text { source }\end{array}$ & $\begin{array}{l}\text { Epigenetic } \\
\text { modulation }\end{array}$ & Gene targets & Biological effects & Cancer type & Reference \\
\hline Phenolic acids & $\begin{array}{l}\text { Hydroxybenzoic acid: } \\
\text { gallic acid } \\
\text { Hydroxycinnamic } \\
\text { acid: Caffeic acid, } \\
\text { curcumin }\end{array}$ & $\begin{array}{l}\text { Red fruit, } \\
\text { onions, black } \\
\text { radish, } \\
\text { cereals, } \\
\text { sage, } \\
\text { oregano }\end{array}$ & $\begin{array}{l}\text { DNMT1, } \\
\text { DNMT3b, } \\
\text { DNMT3a, } \\
\text { HDAC1, } \\
\text { HDAC4, } \\
\text { HDAC7 }\end{array}$ & $\begin{array}{l}\text { RASSF1A, } \\
\text { RAR } \beta, \text { DLC1, } \\
\text { p15INK4b, } \\
\text { Nrf2 }\end{array}$ & $\begin{array}{l}\text { Chemoprevention, cell } \\
\text { growth inhibition, cell } \\
\text { cycle arrest, apoptosis }\end{array}$ & $\begin{array}{l}\text { Breast, lung, } \\
\text { leukemia, } \\
\text { prostate }\end{array}$ & $\begin{array}{l}\text { Du et al., 2012; } \\
\text { Yu et al., 2013; } \\
\text { Liu et al., 2017; } \\
\text { Li et al., } 2018\end{array}$ \\
\hline Stilbenes & Resveratrol & $\begin{array}{l}\text { Red wine, } \\
\text { black berry, } \\
\text { peanuts, } \\
\text { grape } \\
\text { skin }\end{array}$ & DNMT, HDAC & $\begin{array}{l}\text { RASSF1A, } \\
\text { p16, APC, } \\
\text { CCND2, } \\
\text { AURKA, } \\
\text { MMP9, IL8, } \\
\text { AMY2A, } \\
\text { MTA1, SIRT1, } \\
\gamma \text {-H2AX, } \\
\text { hTERT, } \\
\text { BCRA-1, MDR1 }\end{array}$ & $\begin{array}{l}\text { Chemopreventive, } \\
\text { apoptosis }\end{array}$ & $\begin{array}{l}\text { Breast, } \\
\text { prostate }\end{array}$ & $\begin{array}{l}\text { Kai et al., 2010; } \\
\text { Papoutsis et al., } \\
\text { 2010; Zhu et al., } \\
\text { 2012; Zadi } \\
\text { Heydarabad } \\
\text { et al., 2018; Kala } \\
\text { et al., 2015; } \\
\text { Medina-Aguilar } \\
\text { et al., } 2016\end{array}$ \\
\hline Lignans & $\begin{array}{l}\text { Secoisolariciresinol, } \\
\text { matairesinol, } \\
\text { arctigenin, } \\
\text { nordihydroguaiaretic } \\
\text { acid (NDGA) }\end{array}$ & $\begin{array}{l}\text { Tea, coffee, } \\
\text { unrefined } \\
\text { cereals }\end{array}$ & HDACs & $\begin{array}{l}\mathrm{Bc} 2, \\
\mathrm{p} 16 \mathrm{NK} 4 \mathrm{a}\end{array}$ & $\begin{array}{l}\text { Apoptosis, cell cycle } \\
\text { arrest }\end{array}$ & Breast & $\begin{array}{l}\text { Cui et al., 2008; } \\
\text { Hsieh et al., } \\
2014\end{array}$ \\
\hline
\end{tabular}


TABLE 1 | Continued

\begin{tabular}{|c|c|c|c|c|c|c|c|}
\hline $\begin{array}{l}\text { Phytochemical } \\
\text { group }\end{array}$ & Compound & $\begin{array}{l}\text { Natural } \\
\text { source }\end{array}$ & $\begin{array}{l}\text { Epigenetic } \\
\text { modulation }\end{array}$ & Gene targets & Biological effects & Cancer type & Reference \\
\hline Tannins & $\begin{array}{l}\text { Gallotannins } \\
\text { ellagitannins }\end{array}$ & $\begin{array}{l}\text { Black } \\
\text { raspberries }\end{array}$ & ND & ND & ND & ND & \\
\hline $\begin{array}{l}\text { Organosulfur } \\
\text { compounds }\end{array}$ & $\begin{array}{l}\text { Sulforaphane } \\
\text { isothiocyanates }\end{array}$ & $\begin{array}{l}\text { Cauliflower, } \\
\text { brussels } \\
\text { sprouts, } \\
\text { cabbage, } \\
\text { broccoli }\end{array}$ & $\begin{array}{l}\text { DNMT1 } \\
\text { DNMT3a, } \\
\text { DNMT3b, } \\
\text { HDACs 1, 4, } \\
5 \text {, and } 7\end{array}$ & $\begin{array}{l}\text { Nrf2, cyclin } \\
\text { D2, hTERT, } \\
\text { TGFBR1, } \\
\text { CCR4, } \\
\text { p21 WAF1 }\end{array}$ & $\begin{array}{l}\text { Chemopreventive, cell } \\
\text { cycle arrest, apoptosis, } \\
\text { cell growth inhibition }\end{array}$ & $\begin{array}{l}\text { Prostate, } \\
\text { breast, colon }\end{array}$ & $\begin{array}{l}\text { Meeran et al., } \\
\text { 2010; Clarke et al., } \\
\text { 2011; Hsu et al., } \\
\text { 2011; Rajendran } \\
\text { et al., 2011; Zhang } \\
\text { Y. et al., 2013; } \\
\text { Wong et al., 2014 }\end{array}$ \\
\hline
\end{tabular}

\section{Epigenetic Modulation by Quercetin in Cancer}

Quercetin is a flavonoid found in fruits and vegetables such as onions, red wine, green tea, and apples. In tumor cells, quercetin blocked cell cycle and induced pro-apoptotic effects without affecting normal cells (Gibellini et al., 2011; Chirumbolo, 2013). Moreover, Xiao et al. (2011) reported that quercetin inhibited the binding of transactivators CREB2, $\mathrm{C}-J u n, \mathrm{C} / \mathrm{EBP} \beta$ and NF- $\mathrm{KB}$ and blocked the recruitment of the coactivator p300 to COX-2 promoter. Also, quercetin inhibited p300 HAT activity, thereby attenuating the p300mediated acetylation of NF- $\mathrm{KB}$ (Xiao et al., 2011). On the other hand, Tan et al. (2009) showed that quercetin inhibited tumor growth by activation of p16INK4a induced by promoter demethylation in colorectal cancer cells. In leukemic HL-60 cell line, quercetin promotes cell death by FasL expression mediated by $\mathrm{H} 3$ acetylation (Lee et al., 2011). Combinations of quercetin and curcumin restored protein levels of AR in androgen-receptor negative prostate cancer cells. These effects were mediated by decreasing of DNMT, resulting in global hypomethylation and induction of apoptosis via mitochondrial depolarization.

Interestingly, the synergistic effects of quercetin and curcumin combined treatment resulted in sensitization of resistant prostatic cancer cells to anti-androgen treatment (Sharma et al., 2016). In esophageal cancer, combinations of quercetin and sodium butyrate repress tumor growth and cell proliferation which was associated with downregulation of DNMT1, NF-кBp65, HDAC1, and cyclin D1. These combination inhibited HDAC through HDAC-NF-KB signaling (Zheng et al., 2014). On the other hand, quercetin exerted modulatory effects on proteins that have pivotal role in cell survival, invasiveness, angiogenesis and cell proliferation through inhibition of HDAC1 and DNMT1 in hamster buccal pouch carcinoma (Priyadarsini et al., 2011).

\section{Epigenetic Modulation by Resveratrol in Cancer}

Resveratrol is a phytoalexin found in many plants such as blueberries, cranberries, and grapes. This polyphenol provide chemopreventive and therapeutics effects in different types of cancer regulating biological functions such as cell proliferation, cell division, apoptosis, angiogenesis and metastasis (Singh et al., 2013; Berman et al., 2017; Borriello, 2017). In DU145 (mutant p53) and LNCaP (wild type p53) prostate cancer cell lines, resveratrol downregulated the Metastasis Associated Protein 1 (MTA1) leading to destabilization of MTA1/NuRD, a nucleosome remodeling deacetylation (NuRD) corepressor complex that mediates posttranslational modifications of histones and non-histone proteins resulting in transcriptional repression (Kai et al., 2010). Downregulation of MTA1 leads to destabilization of MTA1/NuRD thus allowing acetylation/activation of p53. Additionally, combination of resveratrol and HDAC inhibitor SAHA, up-regulated p53 acetylated non-acetylated forms (Kai et al., 2010). Dhar et al. (2015) showed that resveratrol promotes acetylation and reactivation of PTEN by inhibition of the MTA1/HDAC complex, as well as inhibition of the Akt pathway. Thus, MTA1/HDAC complex is a negative regulator of PTEN, which promotes tumor cell survival and progression of prostate cancer.

In breast cancer cell lines, combination of resveratrol and pterostilbene inhibited cell proliferation, by inducing G2/M phase cell cycle arrest and apoptosis (Kala et al., 2015). The dual treatment blocked SIRT1 and decreased the expression of $\gamma-\mathrm{H} 2 \mathrm{AX}$, thus delaying the early DNA damage response. Also, these compounds cause down-regulation of DNMT1, DNMT3a and DNMT3b in HCC1806 breast cancer cells. Moreover, resveratrol and pterostilbene negatively regulated hTERT leading to inhibition of breast cancer cells growth due to the inhibition of SIRT (Kala et al., 2015). In addition, these combinations induced the reactivation of ER$\alpha$ expression in ER- $\alpha$ negative breast cancer cells, sensitizing tumor cells to $17 \beta$-estradiol treatment which was associated to an increase in $\mathrm{H} 3 \mathrm{~K} 9$ and $\mathrm{H} 4$ marks in the $\mathrm{ER} \alpha$ promoter (Kala and Tollefsbol, 2016).

Another study has showed the profound effects of resveratrol on global DNA methylation in breast cancer. Our group reported that resveratrol modulated the methylation status of a specific broad set of genes independently of DNMT1 inhibition in MDA-MB-231 breast cancer cells. We performed an Array-PRIMES method (aPRIMES) and DNA microarrays to screen changes in both methylome and transcriptome at genome-wide level in cancer cells treated with resveratrol at 24 and $48 \mathrm{~h}$. The integrative analysis of methylome and transcriptome profiles in response to resveratrol showed that methylation alterations were concordant with changes 
in mRNA expression. These changes were found in several oncogenes (AURKA, CCNB1, DDIT4, DLGAP5, EYS, FAM83D, IL24, LPXN, NFIL3, PFKFB3, SLC14A1, STC1, GPR110, HK2, MMP9, NFIL3, PSMD11, RUNX2, SH3KBP1) and tumor suppressor genes (AMY2A, IL18, SLIT3, MPHOSPH9, SLC27A2, TMOD2, TTI1, and XYLB) (Medina-Aguilar et al., 2016). In human A2058 melanoma cells and MDA-MB-468 breast cancer cells, resveratrol reduced the STAT3 acetylation, inducing demethylation of the ER- $\alpha$ promoter region leading to its expression. Resveratrol also sensitized to antiestrogen therapy, decreasing cell viability and cell death. A similar effect was also observed in the M223 melanoma cells resistant to tamoxifen (Lee H. et al., 2012).

\section{Epigenetic Modulation by Sulforaphane in Cancer}

Sulforaphane is a phytochemical derived from cruciferous vegetables. In cancer cells, SFN regulates cell cycle, apoptosis, tumor growth, and tumor progression (Atwell et al., 2015; Kim and Park, 2016). Gao et al. (2018) reported that the miR-9-3 promoter region is hypermethylated in lung cancer cells. Interestingly, SFN restored the miR-9-3 expression through epigenetic regulation attenuating the DNMT1 activity and DNMT3a, HDAC1, HDAC3, HDAC6, and CDH1 protein expression.

Meeran et al. (2010) reported that SFN treatment diminished cell viability and cell proliferation in breast cancer cells. Also, SFN inhibited hTERT in MCF-7 and MDA-MB-231 cancer cells, decreasing DNMT1 and DNMT3a. The downregulation of DNMTs in response to SFN induced CpG demethylation of hTERT thereby facilitating CTCF binding associated with hTERT repression. SFN increased the level of active chromatin markers $\mathrm{H} 3 \mathrm{~K} 9 \mathrm{ac}$ and acetyl-H4, and suppressed $\mathrm{H} 3 \mathrm{~K} 9 \mathrm{me} 3$ and H3K27me3 in hTERT promoter. Altogether, these epigenetic events induced breast cancer cells death. Moreover, combined treatments with SFN and withaferin A promoted cell death in breast cancer cells through the inhibition of DNMT1, DNMT3a, and HDAC activities in MCF-7 cells (Royston et al., 2017).

In prostate cancer cells, SFN inhibited the expression of hTERT by changes in histone acetylation and chromatin structure. In LNCaP and DU-145 cells, SFN caused an inhibitory effect in cell proliferation and induced cell cycle arrest at G0/G1 phase. In the LNCaP cell line, SFN modified the global methylation through their negative regulation of DNMT1, DNMT3a, and DNMT3b. Also, SFN induced methylation and inhibited the HDAC activities of hTERT promoter associated with $\mathrm{H} 3 \mathrm{~K} 4 \mathrm{me} 2, \mathrm{H} 3 \mathrm{~K} 9 \mathrm{me} 3$ and $\mathrm{H} 3 \mathrm{~K} 27 \mathrm{me} 3$ epigenetic marks. Regarding to DU-145 cells, SFN increased the H3K18Ac and H3K4me2 marks. These modifications were linked with high risk of prostate cancer recurrence (Abbas et al., 2016). Other effects of SFN in LNCaP cells were the decrease expression of DNMT1 and DNMT3b, and the decrease methylation of cyclin D2 promoter (Hsu et al., 2011). SFN also caused demethylation of CpGs islands of Nrf2 gene promoter, which acts as regulator in the cellular oxidative stress decreasing the carcinogen-induced tumorigenesis, in TRAMP $\mathrm{C} 1$ cells. Moreover, SFN decreased the levels of DNMT1 and DNMT3a and downregulated the expression of HDACs 1, 4, 5, and 7, while increased the levels of the active $\mathrm{H} 3 \mathrm{ac}$ chromatin marker (Zhang C. et al., 2013). In HeLa cervical cancer cells, SFN exerted negative effects on DNMT1 and HDAC1 activities. Ali Khan et al. (2015) showed that SNF increased the expression of RAR $\beta, C D H 1$, DAPK1, and GSTP1 by restoring the $\mathrm{CpG}$ island methylation status and inhibition of epigenetic modulators like DNMT3b and HDAC1 in cervical cancer.

\section{BIOLOGICAL EFFECTS OF FRUIT AND VEGETABLES CONSUMPTION IN HUMAN}

Fruit and vegetables and healthy lifestyles are considered protective against cancer development. Recently, The European Prospective Investigation into Cancer and Nutrition (EPIC) realized a multicenter study including 13 European countries for analyzing the association of vegetables and fruit intakes and the cancer risk development for a period from 6.5 to 8.7 years. This center concludes that consumption of vegetables and fruits do not have protector effect in patients with lung, prostate, and breast cancers. However, intake of vegetables and fruits or their combinations, or fruit juice reduced the risk of gastric, esophageal and thyroid cancer (Gonzālez et al., 2006, 2012; Boffetta et al., 2010; Linseisen et al., 2010; Zamora-Ros et al., 2018). In addition, the intake of red and processed meat were correlated with colorectal cancer and non-cardia stomach cancer risk in subjects carriers of Helicobacter pylori. Furthermore, the consumption of cereal fiber reduced the risk of gastric cancer mainly diffuse type (Mendez et al., 2007). In contrast, in esophageal adenocarcinoma non-significant trend was found (Gonzalez and Riboli, 2006). The effects of intake of vegetables and fruit on prevention of cancer are restricted due to the bioavailability and low concentration of these phytochemical naturals. In recent years, the use complementary and alternative medicine has increased in order to improve the quality and life expectancy of cancer patients. It is important to note that complementary medicine may be used in combination with chemotherapy, radiotherapy or other forms of therapies, but still is not considered as a standard option. However, the establishment of integrative therapies that combines standard care with alternative practices and lifestyles should be considered as a future option in preventive medicine (Molassiotis et al., 2005; Adams and Jewell, 2007; Abdallah et al., 2015).

\section{CONCLUSION AND PERSPECTIVES}

This review provides recent evidences of the dietary polyphenols and their effects anti-tumors by targeting the epigenetic machinery and related mechanisms. These natural phytochemical 
have potential benefit due to their reverting effects in the epigenetic modifications in tumor suppressor genes and oncogenes, as well as its ability to modulate and restore protein expression levels. The polyphenols cause effects in several biological functions as cell proliferation inhibition, cell cycle arrest, and induction of apoptosis in tumor cells. On the other hand, the epidemiological evidence shows that these compounds may prevents the risk of certain types of cancer development. Thus, it has been considered that these phytochemicals may increase the anti-tumor activity of standard treatments. However, the bioavailability of polyphenolic compounds in the organism is very variable depending on its chemical structure and its origin source, as well as host factors as age, gender, metabolic rate, ethnicity, etc. For all these aspects is required to establish dietary supplements in order to maintain high concentrations in plasma, for that these compounds exert its chemopreventive and therapeutic effects in cancer. Different researches show that polyphenols sensitize tumor cells through different epigenetic targets including oncogenes and tumor suppressor genes as well as DNMTs and HDACs. In addition, the combination of the polyphenols with chemotherapeutic agents exerts a synergistic effect, enhancing the effects of chemotherapeutic agents. However, it is necessary to establish more comprehensive studies that help to understand the complexity of the epigenetic pathways and their mechanisms involved in cancer, especially in highly aggressive and invasive cancers showing resistance to conventional therapies. Future research should

\section{REFERENCES}

Abbas, A., Hall, J. A., Patterson, W. L. III, Ho, E., Hsu, A., Al-Mulla, F., et al. (2016). Sulforaphane modulates telomerase activity via epigenetic regulation in prostate cancer cell lines. Biochem. Cell Biol. 94, 71-81. doi: 10.1139/bcb2015-0038

Abdallah, R., Xiong, Y., Lancaster, J. M., and Judson, P. L. (2015). Complementary and alternative medicine use in women with gynecologic malignancy presenting for care at a comprehensive cancer center. Int. J. Gynecol. Cancer 25, 1724-1730. doi: 10.1097/IGC.0000000000000549

Adams, M., and Jewell, A. P. (2007). The use of complementary and alternative medicine by cancer patients. In International Seminars in Surgical Oncology. BioMed. Central 4:10. doi: 10.1186/1477-7800-4-10

Adjakly, M., Bosviel, R., Rabiau, N., Boiteux, J. P., Bignon, Y. J., Guy, L., et al. (2011). DNA methylation and soy phytoestrogens: quantitative study in DU145 and PC-3 human prostate cancer cell lines. Epigenomics 3, 795-803. doi: 10.2217/epi.11.103

Adjakly, M., Ngollo, M., Lebert, A., Dagdemir, A., Penault-Llorca, F., Boiteux, J. P., et al. (2014). Comparative effects of soy phytoestrogens and $17 \beta$-estradiol on DNA methylation of a panel of 24 genes in prostate cancer cell lines. Nutr. Cancer 66, 474-482. doi: 10.1080/01635581.2014.884236

Aggarwal, R., Jha, M., Shrivastava, A., and Jha, A. K. (2015). Natural compounds: role in reversal of epigenetic changes. Biochemistry 80, 972-989. doi: 10.1134/ S0006297915080027

Ali Khan, M. K., Sundaram, M., Hamza, A., Quraishi, U., Gunasekera, D., Ramesh, L., et al. (2015). Sulforaphane reverses the expression of various tumor suppressor genes by targeting DNMT3B and HDAC1 in human cervical cancer cells. Evid. Based Complement. Alternat. Med. doi: 10.1155/2015/412149

Atwell, L. L., Beaver, L. M., Shannon, J., Williams, D. E., Dashwood, R. H., and Ho, E. (2015). Epigenetic regulation by sulforaphane: opportunities for breast and prostate cancer chemoprevention. Curr. Pharmacol. Rep. 1, 102-111. doi: 10.1007/s40495-014-0002-x be focused in clinical studies in humans for establishing potential personalized regimens for cancer prevention or chemotherapeutic approaches in cancer.

\section{AUTHOR CONTRIBUTIONS}

CL-C, ÁC-R, and JSL-G organized the entire manuscript, wrote the draft, and revised the last version of manuscript. MM-F, ÁC-R, and JSL-G wrote the introduction, epigenetic mechanisms, and phytochemicals sections. DG-R, ER-G, and HA-dlV wrote the epigenetic modulation by EGCG and curcumin in cancer sections. ÁC-R, JSL-G, and ONHdlC wrote the epigenetic modulation by quercetin, resveratrol, and SFN sections. ÁC-R, LAM and MM-F wrote the modulation of signaling pathways by polyphenols sections. Figures 1-3, as well as Table 1 were designed and made by ÁC-R, JSL-G and ONHdlC.

\section{ACKNOWLEDGMENTS}

We acknowledge to Consejo Nacional de Ciencia y Tecnología (CONACYT; Mexico), Fondo de Investigación Científica Básica (Grant No. 222335), and Fondo SSA/IMSS/ISSSTE (Grant No. 233370) for financial support. Also we acknowledge to Universidad Autonoma de la Ciudad de Mexico and Instituto Nacional de Enfermedades Respiratorias "Ismael Cosio Villegas" for support.

Bag, A., and Bag, N. (2018). Tea polyphenols and prevention of epigenetic aberrations in cancer. J. Nat. Sci. Biol. Med. 9, 2-5. doi: 10.4103/jnsbm.JNSBM_46_17

Bannister, A. J., and Kouzarides, T. (2011). Regulation of chromatin by histone modifications. Cell Res. 21:381. doi: 10.1038/cr.2011.22

Bégin, P., and Nadeau, K. C. (2014). Epigenetic regulation of asthma and allergic disease. Allergy Asthma Clin. Immunol. 10:27. doi: 10.1186/17101492-10-27

Benard, A., Goossens-Beumer, I. J., van Hoesel, A. Q., de Graaf, W., Horati, H., Putter, H., et al. (2014). Histone trimethylation at H3K4, H3K9 and H4K20 correlates with patient survival and tumor recurrence in early-stage colon cancer. BMC Cancer 14:531. doi: 10.1186/1471-2407-14-531

Berdasco, M., and Esteller, M. (2010). Aberrant epigenetic landscape in cancer: how cellular identity goes awry. Dev. Cell 19, 698-711. doi: 10.1016/j.devcel.2010.10.005

Berletch, J. B., Liu, C., Love, W. K., Andrews, L. G., Katiyar, S. K., and Tollefsbol, T. O. (2008). Epigenetic and genetic mechanisms contribute to telomerase inhibition by EGCG. J. Cell. Biochem. 103, 509-519. doi: 10.1002/jcb.21417

Berman, A. Y., Motechin, R. A., Wiesenfeld, M. Y., and Holz, M. K. (2017). The therapeutic potential of resveratrol: a review of clinical trials. NPJ Precis. Oncol. 1:35. doi: 10.1038/s41698-017-0038-6

Bishayee, K., Khuda-Bukhsh, A. R., and Huh, S. O. (2015). PLGA-loaded goldnanoparticles precipitated with quercetin downregulate HDAC-Akt activities controlling proliferation and activate p53-ROS crosstalk to induce apoptosis in hepatocarcinoma cells. Mol. Cells 38, 518-527. doi: 10.14348/molcells.2015. 2339

Biterge, B. (2016). A mini review on post-translational histone modifications. MOJ Cell Sci. Rep. 3, 26-28. doi: 10.15406/mojcsr.2016.03.00047

Boffetta, P., Couto, E., Wichmann, J., Ferrari, P., Trichopoulos, D., Bueno-deMesquita, H. B., et al. (2010). Fruit and vegetable intake and overall cancer risk in the European Prospective Investigation into Cancer and Nutrition (EPIC). J. Natl. Cancer Inst. 102, 529-537. doi: 10.1093/jnci/djq072 
Borriello, A. (2017). Resveratrol in cancer prevention and treatment: focusing on molecular targets and mechanism of action. Multidiscip. Dig. Publish. Inst. Proc. 1:976. doi: 10.3390/proceedings1100976

Bosviel, R., Dumollard, E., Déchelotte, P., Bignon, Y. J., and Bernard-Gallon, D. (2012). Can soy phytoestrogens decrease DNA methylation in BRCA1 and BRCA2 oncosuppressor genes in breast cancer? OMICS 16, 235-244. doi: 10. 1089/omi.2011.0105

Chahar, M. K., Sharma, N., Dobhal, M. P., and Joshi, Y. C. (2011). Flavonoids: a versatile source of anticancer drugs. Pharmacogn. Rev. 5, 1-12. doi: 10.4103/ 0973-7847.79093

Chen, H., Landen, C. N., Li, Y., Alvarez, R. D., and Tollefsbol, T. O. (2013). Epigallocatechin gallate and sulforaphane combination treatment induce apoptosis in paclitaxel-resistant ovarian cancer cells through hTERT and Bcl2 down-regulation. Exp. Cell Res. 319, 697-706. doi: 10.1016/j.yexcr.2012. 12.026

Chen, Y. C., Kliethermes, B., and Sauter, E. R. (2012). Trans-resveratrol alters mammary promoter hypermethylation in women at increased risk for breast cancer. Nutr. Cancer 64, 393-390. doi: 10.1080/01635581.2012.654926

Chirumbolo, S. (2013). Quercetin in cancer prevention and therapy. Integr. Cancer Ther. 12, 97-102. doi: 10.1177/1534735412448215

Choudhury, M., Pandey, R. S., Clemens, D. L., Davis, J. W., Lim, R. W., and Shukla, S. D. (2009). Silencing of histone acetyltransferase GCN5 affects gene expression in human hepatoma cells: a gene array analysis. FASEB J. 23(1 Suppl.), 585-588. doi: 10.1016/j.alcohol.2010.12.003

Clarke, J. D., Hsu, A., Yu, Z., Dashwood, R. H., and Ho, E. (2011). Differential effects of sulforaphane on histone deacetylases, cell cycle arrest and apoptosis in normal prostate cells versus hyperplastic and cancerous prostate cells. Mol. Nutr. Food Res. 55, 999-1009. doi: 10.1002/mnfr.201000547

Cohen, I., Poręba, E., Kamieniarz, K., and Schneider, R. (2011). Histone modifiers in cancer: friends or foes? Genes Cancer 2, 631-647. doi: 10.1177/ 1947601911417176

Cui, Y., Lu, C., Liu, L., Sun, D., Yao, N., Tan, S., et al. (2008). Reactivation of methylation-silenced tumor suppressor gene p16INK4a by nordihydroguaiaretic acid and its implication in G1 cell cycle arrest. Life Sci. 82, 247-255. doi: 10.1016/j.lfs.2007.11.013

Cutter, A. R., and Hayes, J. J. (2015). A brief review of nucleosome structure. FEBS Lett. 589(20 Part A), 2914-2922. doi: 10.1016/j.febslet.2015.05.016

Deb, G., and Gupta, S. (2015). "Natural phytochemicals as epigenetic modulators," in Genomics, Proteomics and Metabolomics in Nutraceuticals and Functional Foods, eds D. Bagchi, A. Swaroop, and M. Bagchi (Hoboken, NJ: Wiley), 424-439. doi: 10.1002/9781118930458.ch34

Dhar, S., Kumar, A., Li, K., Tzivion, G., and Levenson, A. S. (2015). Resveratrol regulates PTEN/Akt pathway through inhibition of MTA1/HDAC unit of the NuRD complex in prostate cancer. Biochim. Biophys. Acta Mol. Cell Res. 1853, 265-275. doi: 10.1016/j.bbamcr.2014.11.004

Du, L., Xie, Z., Wu, L. C., Chiu, M., Lin, J., Chan, K. K., et al. (2012). Reactivation of RASSF1A in breast cancer cells by curcumin. Nutr. cancer 64, 1228-1235. doi: 10.1080/01635581.2012.717682

Ehrlich, M. (2009). DNA hypomethylation in cancer cells. Epigenomics 1, 239-259. doi: 10.2217/epi.09.33

El Gharras, H. (2009). Polyphenols: food sources, properties and applications-a review. Int. J. Food Sci. Technol. 44, 2512-2518. doi: 10.1111/j.1365-2621.2009. 02077.x

Ellinger, J., Kahl, P., von der Gathen, J., Rogenhofer, S., Heukamp, L. C., Gütgemann, I., et al. (2009). Global levels of histone modifications predict prostate cancer recurrence. Prostate 70, 61-69. doi: 10.1002/pros.21038

El-Sherif, W. T., Sayed, S. K., Galal, S. H., Makhlouf, H. A., Hassan, A. T., and Yousef, H. A. (2016). Diagnostic role of RASSF1A and p16INK4a promoter gene hypermethylation in serum DNA of lung cancer patients: clinicopathological significance. Egypt. J. Immunol. 23, 1-16.

Estécio, M. R., Gharibyan, V., Shen, L., Ibrahim, A. E., Doshi, K., He, R., et al. (2007). LINE-1 hypomethylation in cancer is highly variable and inversely correlated with microsatellite instability. PLoS One 2:e399. doi: 10.1371/journal. pone.0000399

Esteller, M. (2005). Aberrant DNA methylation as a cancer-inducing mechanism. Annu. Rev. Pharmacol. Toxicol. 45, 629-656. doi: 10.1146/annurev.pharmtox. 45.120403.095832
Esteller, M. (2008). Epigenetics in cancer. New Engl. J. Med. 358, 1148-1159. doi: 10.1056/NEJMra072067

Esteller, M. (2011). Epigenetic changes in cancer. F1000 Biol. Rep. 3:9. doi: 10.3410/B3-9

Esteller, M., and Herman, J. G. (2002). Cancer as an epigenetic disease: DNA methylation and chromatin alterations in human tumours. J. Pathol. 196, 1-7. doi: 10.1002/path.1024

Falcone Ferreyra, M. L., Rius, S., and Casati, P. (2012). Flavonoids: biosynthesis, biological functions, and biotechnological applications. Front. Plant Sci. 3:222. doi: $10.3389 /$ fpls.2012.00222

Fang, M. Z., Chen, D., Sun, Y., Jin, Z., Christman, J. K., and Yang, C. S. (2005). Reversal of hypermethylation and reactivation of p16INK4a, RAR $\beta$, and MGMT genes by genistein and other isoflavones from soy. Clin. Cancer Res. 11, 7033-7041. doi: 10.1158/1078-0432.CCR-05-0406

Fang, M. Z., Wang, Y., Ai, N., Hou, Z., Sun, Y., Lu, H., et al. (2003). Tea polyphenol (-)-epigallocatechin-3-gallate inhibits DNA methyltransferase and reactivates methylation-silenced genes in cancer cell lines. Cancer Res. 63, 7563-7570.

Feng, C., Ho, Y., Sun, C., Xia, G., Ding, Q., and Gu, B. (2017). Epigallocatechin gallate inhibits the growth and promotes the apoptosis of bladder cancer cells. Exp. Ther. Med. 14, 3513-3518. doi: 10.3892/etm.2017.4981

Ganesan, K., and Xu, B. (2017). A critical review on polyphenols and health benefits of black soybeans. Nutrients 9, 455. doi: 10.3390/nu9050455

Gao, L., Cheng, D., Yang, J., Wu, R., Li, W., and Kong, A. N. (2018). Sulforaphane epigenetically demethylates the CpG sites of the miR-9-3 promoter and reactivates miR-9-3 expression in human lung cancer A549 cells. J. Nutr. Biochem. 56, 109-115. doi: 10.1016/j.jnutbio.2018.01.015

Gao, Z. H. I., Xu, Z., Hung, M. S., Lin, Y. C., Wang, T., Gong, M., et al. (2009). Promoter demethylation of WIF-1 by epigallocatechin-3-gallate in lung cancer cells. Anticancer Res. 29, 2025-2030.

Gibellini, L., Pinti, M., Nasi, M., Montagna, J. P., De Biasi, S., Roat, E., et al. (2011). Quercetin and cancer chemoprevention. Evid. Based Complement. Alternat. Med. 2011:591356. doi: 10.1093/ecam/neq053

Glant, T. T., Mikecz, K., and Rauch, T. A. (2014). Epigenetics in the pathogenesis of rheumatoid arthritis. BMC Med. 12:35. doi: 10.1186/1741-7015-12-35

Gonzālez, C. A., Jakszyn, P., Pera, G., Agudo, A., Bingham, S., Palli, D., et al. (2006). Meat intake and risk of stomach and esophageal adenocarcinoma within the European Prospective Investigation Into Cancer and Nutrition (EPIC). J. Natl. Cancer Inst. 98, 345-354. doi: 10.1093/jnci/djj071

Gonzalez, C. A., Lujan-Barroso, L., Bueno-de-Mesquita, H. B., Jenab, M., Duell, E. J., Agudo, A., et al. (2012). Fruit and vegetable intake and the risk of gastric adenocarcinoma: a reanalysis of the European Prospective Investigation into Cancer and Nutrition (EPIC-EURGAST) study after a longer follow-up. Int. J. Cancer 131, 2910-2919. doi: 10.1002/ijc.27565

Gonzalez, C. A., and Riboli, E. (2006). Diet and cancer prevention: where we are, where we are going. Nutr. Cancer 56, 225-231. doi: 10.1207/s15327914nc5602_14

Greenlee, H. (2012). Natural Products for Cancer Prevention. In Seminars in Oncology Nursing, Vol. 28. Philadelphia, PA: WB Saunders, 29-44. doi: 10.1016/ j.soncn.2011.11.004

Guo, Y., Shu, L., Zhang, C., Su, Z. Y., and Kong, A. N. T. (2015). Curcumin inhibits anchorage-independent growth of HT29 human colon cancer cells by targeting epigenetic restoration of the tumor suppressor gene DLEC1. Biochem. Pharmacol. 94, 69-78. doi: 10.1016/j.bcp.2015.01.009

Guo, Y., Su, Z. Y., and Kong, A. N. T. (2015). Current perspectives on epigenetic modifications by dietary chemopreventive and herbal phytochemicals. Curr. Pharmacol. Rep. 1, 245-257. doi: 10.1007/s40495-015-0023-0

Gupta, K., Thakur, V. S., Bhaskaran, N., Nawab, A., Babcook, M. A., Jackson, M. W., et al. (2012). Green tea polyphenols induce p53dependent and p53-independent apoptosis in prostate cancer cells through two distinct mechanisms. PLoS One 7:e52572. doi: 10.1371/journal.pone. 0052572

Haldrup, C., Storebjerg, T. M., Vestergaard, E. M., Wild, P. J., Høyer, S., and Sørensen, K. D. (2017). Comprehensive evaluation of TFF3 promoter hypomethylation and molecular biomarker potential for prostate cancer diagnosis and prognosis. Int. J. Mol. Sci. 18:E2017. doi: 10.3390/ijms18092017

Hardman, W. E. (2014). Diet components can suppress inflammation and reduce cancer risk. Nutr. Res. Pract. 8, 233-240. doi: 10.4162/nrp.2014.8.3.233 
Henning, S. M., Wang, P., Said, J., Magyar, C., Castor, B., Doan, N., et al. (2012). Polyphenols in brewed green tea inhibit prostate tumor xenograft growth by localizing to the tumor and decreasing oxidative stress and angiogenesis. J. Nutr. Biochem. 23, 1537-1542. doi: 10.1016/j.jnutbio.2011.10.007

Hewlings, S. J., and Kalman, D. S. (2017). Curcumin: a review of its' effects on human health. Foods 6:92. doi: 10.3390/foods6100092

Hsieh, C. J., Kuo, P. L., Hsu, Y. C., Huang, Y. F., Tsai, E. M., and Hsu, Y. L. (2014). Arctigenin, a dietary phytoestrogen, induces apoptosis of estrogen receptor-negative breast cancer cells through the ROS/p38 MAPK pathway and epigenetic regulation. Free Radic. Biol. Med. 67, 159-170. doi: 10.1016/j. freeradbiomed.2013.10.004

Hsu, A., Wong, C. P., Yu, Z., Williams, D. E., Dashwood, R. H., and Ho, E. (2011). Promoter de-methylation of cyclin D2 by sulforaphane in prostate cancer cells. Clin. Epigenetics 3:3. doi: 10.1186/1868-7083-3-3

Hu, Y. H., Chen, Q., Lu, Y. X., Zhang, J. M., Lin, C., Zhang, F., et al. (2017). Hypermethylation of NDN promotes cell proliferation by activating the Wnt signalin pathway in colorectal cancer. Oncotarget 8:46191. doi: 10.18632/ oncotarget. 17580

Hur, K., Cejas, P., Feliu, J., Moreno-Rubio, J., Burgos, E., Boland, C. R., et al. (2014). Hypomethylation of long interspersed nuclear element-1 (LINE-1) leads to activation of proto-oncogenes in human colorectal cancer metastasis. Gut 63, 635-646. doi: 10.1136/gutjnl-2012-304219

Imperatori, A., Sahnane, N., Rotolo, N., Franzi, F., Nardecchia, E., Libera, L., et al. (2017). LINE-1 hypomethylation is associated to specific clinico-pathological features in Stage I non-small cell lung cancer. Lung Cancer 108, 83-89. doi: 10.1016/j.lungcan.2017.03.003

Jabeena, S., Hanifa, M. A., Khanb, M. M., and Qadric, R. W. K. (2014). Natural products sources and their active compounds on disease prevention: a. health. Int. J. Chem. Biochem. Sci. 6:7.

Jiang, A., Wang, X., Shan, X., Li, Y., Wang, P., Jiang, P., et al. (2015). Curcumin reactivates silenced tumor suppressor gene RAR $\beta$ by reducing DNA methylation. Phytother. Res. 29, 1237-1245. doi: 10.1002/ptr.5373

Jin, B., Li, Y., and Robertson, K. D. (2011). DNA methylation: superior or subordinate in the epigenetic hierarchy? Genes Cancer 2, 607-617. doi: 10.1177/ 1947601910393957

Joozdani, F. A., Yari, F., Joozdani, P. A., and Nafisi, S. (2015). Interaction of Sulforaphane with DNA and RNA. PLoS One 10:e0127541. doi: 10.1371/journal. pone.0127541

Kagohara, L. T., Stein-O'Brien, G. L., Kelley, D., Flam, E., Wick, H. C., Danilova, L. V., et al. (2017). Epigenetic regulation of gene expression in cancer: techniques, resources and analysis. Brief. Funct. Genom. 17, 49-63. doi: 10.1093/ bfgp/elx018

Kai, L., Samuel, S. K., and Levenson, A. S. (2010). Resveratrol enhances p53 acetylation and apoptosis in prostate cancer by inhibiting MTA1/NuRD complex. Int. J. Cancer 126, 1538-1548. doi: 10.1002/ijc. 24928

Kala, R., Shah, H. N., Martin, S. L., and Tollefsbol, T. O. (2015). Epigenetic-based combinatorial resveratrol and pterostilbene alters DNA damage response by affecting SIRT1 and DNMT enzyme expression, including SIRT1-dependent $\gamma$-H2AX and telomerase regulation in triple-negative breast cancer. BMC Cancer 15:672. doi: 10.1186/s12885-015-1693-Z

Kala, R., and Tollefsbol, T. O. (2016). A novel combinatorial epigenetic therapy using resveratrol and pterostilbene for restoring estrogen receptor- $\alpha$ (ER $\alpha)$ expression in ER $\alpha$-negative breast cancer cells. PLoS One 11:e0155057. doi: 10.1371/journal.pone.0155057

Kang, S. K., Cha, S. H., and Jeon, H. G. (2006). Curcumin-induced histone hypoacetylation enhances caspase-3-dependent glioma cell death and neurogenesis of neural progenitor cells. Stem Cells Dev. 15, 165-174. doi: 10. 1089/scd.2006.15.165

Kanwal, R., Sharma, H., and Gupta, S. (2011). Plant flavonoid apigenin preferentially binds with GC-rich DNA sequences and inhibits DNA methylation. Cancer Res. 71(8 Suppl.), 3683-3683. doi: 10.1158/1538-7445. AM2011-3683

Karlić, R., Chung, H. R., Lasserre, J., Vlahoviček, K., and Vingron, M. (2010). Histone modification levels are predictive for gene expression. Proc. Natl. Acad. Sci. U.S.A. 107, 2926-2931. doi: 10.1073/pnas.0909344107

Kawser Hossain, M., Abdal Dayem, A., Han, J., Yin, Y., Kim, K., Kumar Saha, S., et al. (2016). Molecular mechanisms of the anti-obesity and anti-diabetic properties of flavonoids. Int. J. Mol. Sci. 17:569. doi: 10.3390/ijms17040569
Khan, M. A., Hussain, A., Sundaram, M. K., Alalami, U., Gunasekera, D., Ramesh, L., et al. (2015). (-)-Epigallocatechin-3-gallate reverses the expression of various tumor-suppressor genes by inhibiting DNA methyltransferases and histone deacetylases in human cervical cancer cells. Oncol. Rep. 33, 1976-1984. doi: 10.3892/or.2015.3802

Khor, T. O., Huang, Y., Wu, T. Y., Shu, L., Lee, J., and Kong, A. N. T. (2011). Pharmacodynamics of curcumin as DNA hypomethylation agent in restoring the expression of Nrf2 via promoter CpGs demethylation. Biochem. Pharmacol. 82, 1073-1078. doi: 10.1016/j.bcp.2011.07.065

Kim, J. K., and Park, S. U. (2016). Current potential health benefits of sulforaphane. EXCLI J. 15:571. doi: 10.17179/excli2016-485

Kim, Y. H., Lee, D. H., Jeong, J. H., Guo, Z. S., and Lee, Y. J. (2008). Quercetin augments TRAIL-induced apoptotic death: involvement of the ERK signal transduction pathway. Biochem. Pharmacol. 75, 1946-1958. doi: 10.1016/j.bcp. 2008.02.016

Kocaadam, B., and Şanlier, N. (2017). Curcumin, an active component of turmeric (Curcuma longa), and its effects on health. Crit. Rev. Food Sci. Nutr. 57, 2889-2895. doi: 10.1080/10408398.2015.1077195

Kumar, U., Sharma, U., and Rathi, G. (2017). Reversal of hypermethylation and reactivation of glutathione S-transferase pi 1 gene by curcumin in breast cancer cell line. Tumor Biol. 39:1010428317692258. doi: 10.1177/1010428317692258

Lawrence, M., Daujat, S., and Schneider, R. (2016). Lateral thinking: how histone modifications regulate gene expression. Trends Genet. 32, 42-56. doi: 10.1016/ j.tig.2015.10.007

Lee, H., Zhang, P., Herrmann, A., Yang, C., Xin, H., Wang, Z., et al. (2012). Acetylated STAT3 is crucial for methylation of tumor-suppressor gene promoters and inhibition by resveratrol results in demethylation. Proc. Natl. Acad. Sci. U.S.A. 109, 7765-7769. doi: 10.1073/pnas.1205132109

Lee, W. J., Chen, Y. R., and Tseng, T. H. (2011). Quercetin induces FasL-related apoptosis, in part, through promotion of histone $\mathrm{H} 3$ acetylation in human leukemia HL-60 cells. Oncol. Rep. 25, 583-591. doi: 10.3892/or.2010.1097

Lee, Y. H., Kwak, J., Choi, H. K., Choi, K. C., Kim, S., Lee, J., et al. (2012). EGCG suppresses prostate cancer cell growth modulating acetylation of androgen receptor by anti-histone acetyltransferase activity. Int. J. Mol. Med. 30, 69-74. doi: $10.3892 /$ ijmm.2012.966

Leszinski, G., Gezer, U., Siegele, B., Stoetzer, O., and Holdenrieder, S. (2012). Relevance of histone marks $\mathrm{H} 3 \mathrm{~K} 9 \mathrm{me} 3$ and H4K20me3 in cancer. Anticancer Res. 32, 2199-2205.

Li, S. (2012). Implication of posttranslational histone modifications in nucleotide excision repair. Int. J. Mol. Sci. 13, 12461-12486. doi: 10.3390/ijms131012461

Li, W., Su, Z. Y., Guo, Y., Zhang, C., Wu, R., Gao, L., et al. (2018). Curcumin derivative epigenetically reactivates $\mathrm{Nrf} 2$ antioxidative stress signaling in mouse prostate cancer TRAMP C1 cells. Chem. Res. Toxicol. 31, 88-96. doi: 10.1021/ acs.chemrestox.7b00248

Li, Y., Chen, H., Hardy, T. M., and Tollefsbol, T. O. (2013). Epigenetic regulation of multiple tumor-related genes leads to suppression of breast tumorigenesis by dietary genistein. PLoS One 8:e54369. doi: 10.1371/journal.pone.0054369

Li, Y., Go, V. L. W., and Sarkar, F. H. (2015). The role of nutraceuticals in pancreatic cancer prevention and therapy: targeting cellular signaling, miRNAs and epigenome. Pancreas 44, 1-10. doi: 10.1097/MPA.000000000 0000257

Li, Y., Lu, D. G., Ma, Y. M., and Liu, H. (2017a). Association between Retinoic acid receptor- $\beta$ hypermethylation and NSCLC risk: a meta-analysis and literature review. Oncotarget 8:5814. doi: 10.18632/oncotarget.14023

Li, Y., Meeran, S. M., and Tollefsbol, T. O. (2017b). Combinatorial bioactive botanicals re-sensitize tamoxifen treatment in ER-negative breast cancer via epigenetic reactivation of ER $\alpha$ expression. Sci. Rep. 7:9345. doi: 10.1038/s41598017-09764-3

Li, Y., Yuan, Y. Y., Meeran, S. M., and Tollefsbol, T. O. (2010). Synergistic epigenetic reactivation of estrogen receptor- $\alpha(\operatorname{ER} \alpha)$ by combined green tea polyphenol and histone deacetylase inhibitor in $\mathrm{ER} \alpha$-negative breast cancer cells. Mol. Cancer 9:274. doi: 10.1186/1476-4598-9-274

Lim, D. H., and Maher, E. R. (2010). DNA methylation: a form of epigenetic control of gene expression. Obstetr. Gynaecol. 12, 37-42. doi: 10.1576/toag.12.1.037. 27556

Link, A., Balaguer, F., Shen, Y., Lozano, J. J., Leung, H. C. E., Boland, C. R., et al. (2013). Curcumin modulates DNA methylation in colorectal cancer cells. PLoS One 8:e57709. doi: 10.1371/journal.pone.0057709 
Linseisen, J., Kim, C. A., Overvad, K., Nielsen, M. R. S., Tjønneland, A., Olsen, A., et al. (2010). Fruit and vegetable intake and overall cancer risk in the European Prospective Investigation into Cancer and Nutrition (EPIC). J. Natl. Cancer Inst. 102, 529-537. doi: 10.1093/jnci/djq072

Liu, X., Sun, C., Liu, B., Jin, X., Li, P., Zheng, X., et al. (2016). Genistein mediates the selective radiosensitizing effect in NSCLC A549 cells via inhibiting methylation of the keap1 gene promoter region. Oncotarget 7:27267. doi: 10. 18632/oncotarget.8403

Liu, Y., Zhou, J., Hu, Y., Wang, J., and Yuan, C. (2017). Curcumin inhibits growth of human breast cancer cells through demethylation of DLC1 promoter. Mol. Cell. Biochem. 425, 47-58. doi: 10.1007/s11010-016-2861-4

Luczak, M. W., and Jagodziński, P. P. (2006). The role of DNA methylation in cancer development. Folia Histochem. Cytobiol. 44, 143-154.

Mahmoud, A. M., Al-Alem, U., Ali, M. M., and Bosland, M. C. (2015). Genistein increases estrogen receptor beta expression in prostate cancer via reducing its promoter methylation. J. Steroid Biochem. Mol. Biol. 152, 62-75. doi: 10.1016/j. jsbmb.2015.04.018

Majid, S., Dar, A. A., Shahryari, V., Hirata, H., Ahmad, A., Saini, S., et al. (2010). Genistein reverses hypermethylation and induces active histone modifications in tumor suppressor gene B-Cell translocation gene 3 in prostate cancer. Cancer 116, 66-76. doi: $10.1002 / \mathrm{cncr} .24662$

Majid, S., Kikuno, N., Nelles, J., Noonan, E., Tanaka, Y., Kawamoto, K., et al. (2008). Genistein induces the p21WAF1/CIP1 and p16INK4a tumor suppressor genes in prostate cancer cells by epigenetic mechanisms involving active chromatin modification. Cancer Res. 68, 2736-2744. doi: 10.1158/0008-5472.CAN-072290

Manach, C., Scalbert, A., Morand, C., Rémésy, C., and Jiménez, L. (2004). Polyphenols: food sources and bioavailability. Am. J. Clin. Nutr. 79, 727-747. doi: 10.1093/ajen/79.5.727

Mariño-Ramírez, L., Kann, M. G., Shoemaker, B. A., and Landsman, D. (2005). Histone structure and nucleosome stability. Expert Rev. Proteomics 2, 719-729. doi: 10.1586/14789450.2.5.719

Marmorstein, R., and Zhou, M. M. (2014). Writers and readers of histone acetylation: structure, mechanism, and inhibition. Cold Spring Harb. Perspect. Biol. 6:a018762. doi: 10.1101/cshperspect.a018762

McCleary-Wheeler, A. L., Lomberk, G. A., Weiss, F. U., Schneider, G., Fabbri, M., Poshusta, T. L., et al. (2013). Insights into the epigenetic mechanisms controlling pancreatic carcinogenesis. Cancer Lett. 328, 212-221. doi: 10.1016/ j.canlet.2012.10.005

Medina-Aguilar, R., Pérez-Plasencia, C., Marchat, L. A., Gariglio, P., Mena, J. G., Cuevas, S. R., et al. (2016). Methylation landscape of human breast cancer cells in response to dietary compound resveratrol. PLoS One 11:e0157866. doi: 10.1371/journal.pone.0157866

Meeran, S. M., Patel, S. N., Chan, T. H., and Tollefsbol, T. O. (2011). A novel prodrug of epigallocatechin-3-gallate: differential epigenetic hTERT repression in human breast cancer cells. Cancer Prevent. Res. 4, 1243-1254. doi: 10.1158/ 1940-6207.CAPR-11-0009

Meeran, S. M., Patel, S. N., and Tollefsbol, T. O. (2010). Sulforaphane causes epigenetic repression of hTERT expression in human breast cancer cell lines. PLoS One 5:e11457. doi: 10.1371/journal.pone.0011457

Mendez, M. A., Pera, G., Agudo, A., Bueno-de-Mesquita, H. B., Palli, D., Boeing, H., et al. (2008). Cereal fiber intake may reduce risk of gastric adenocarcinomas: the EPIC-EURGAST study (International Journal of Cancer (2007) 121, (1618-1623)). Int. J. Cancer 123:2228. doi: 10.1002/ijc. 22896

Meng, J., Tong, Q., Liu, X., Yu, Z., Zhang, J., and Gao, B. (2017). Epigallocatechin3 -gallate inhibits growth and induces apoptosis in esophageal cancer cells through the demethylation and reactivation of the p16 gene. Oncol. Lett. 14, 1152-1156. doi: 10.3892/ol.2017.6248

Molassiotis, A., Fernadez-Ortega, P., Pud, D., Ozden, G., Scott, J. A., Panteli, V., et al. (2005). Use of complementary and alternative medicine in cancer patients: a European survey. Ann. Oncol. 16, 655-663. doi: 10.1093/annonc/ mdil10

Moore, L. D., Le, T., and Fan, G. (2013). DNA methylation and its basic function. Neuropsychopharmacology 38:23. doi: 10.1038/nnp.2012.112

Mossman, D., and Scott, R. J. (2006). Epimutations, inheritance and causes of aberrant DNA methylation in cancer. Hered. Cancer Clin. Pract. 4, 75-80. doi: $10.1186 / 1897-4287-4-2-75$
Nandakumar, V., Vaid, M., and Katiyar, S. K. (2011). (-)-Epigallocatechin-3-gallate reactivates silenced tumor suppressor genes, Cip1/p21 and p 16 INK4a, by reducing DNA methylation and increasing histones acetylation in human skin cancer cells. Carcinogenesis 32, 537-544. doi: 10.1093/carcin/bgq285

Natarajan, T., Anandhi, M., Aiswarya, D., Ramkumar, R., Kumar, S., and Perumal, P. (2016). Idaein chloride induced p53 dependent apoptosis in cervical cancer cells through inhibition of viral oncoproteins. Biochimie 121, 13-20. doi: 10.1016/j.biochi.2015.11.008

Niesen, D. B., Hessler, C., and Seeram, N. P. (2013). Beyond resveratrol: a review of natural stilbenoids identified from 2009-2013. J. Berry Res. 3, 181-196. doi: 10.3233/JBR-130062

Nørgaard, M., Haldrup, C., Storebjerg, T. M., Vestergaard, E. M., Wild, P. J., Høyer, S., et al. (2017). Comprehensive Evaluation of TFF3 promoter hypomethylation and molecular biomarker potential for prostate cancer diagnosis and prognosis. Int. J. Mol. Sci. 18:E2017. doi: 10.3390/ijms18092017

Pandey, M., Kaur, P., Shukla, S., Abbas, A., Fu, P., and Gupta, S. (2012). Plant flavone apigenin inhibits HDAC and remodels chromatin to induce growth arrest and apoptosis in human prostate cancer cells: in vitro and in vivo study. Mol. Carcinog. 51, 952-962. doi: 10.1002/mc.20866

Pandey, M., Shukla, S., and Gupta, S. (2010). Promoter demethylation and chromatin remodeling by green tea polyphenols leads to re-expression of GSTP1 in human prostate cancer cells. Int. J. Cancer 126, 2520-2533. doi: $10.1002 / \mathrm{ijc} .24988$

Papoutsis, A. J., Lamore, S. D., Wondrak, G. T., Selmin, O. I., and Romagnolo, D. F. (2010). Resveratrol prevents epigenetic silencing of BRCA-1 by the aromatic hydrocarbon receptor in human breast cancer cells. J. Nutr. 140, 1607-1614. doi: $10.3945 /$ in. 110.123422

Park, S. Y., Seo, A. N., Jung, H. Y., Gwak, J. M., Jung, N., Cho, N. Y., et al. (2014). Alu and LINE-1 hypomethylation is associated with HER2 enriched subtype of breast cancer. PLoS One 9:e100429. doi: 10.1371/journal.pone.0100429

Prakash, K., and Fournier, D. (2017). Histone code and higher-order chromatin folding: a hypothesis. Genom. Comput. Biol. 3:41. doi: 10.18547/gcb.2017.vol3. iss2.e41

Priyadarsini, R. V., Vinothini, G., Murugan, R. S., Manikandan, P., and Nagini, S. (2011). The flavonoid quercetin modulates the hallmark capabilities of hamster buccal pouch tumors. Nutr. Cancer 63, 218-226. doi: 10.1080/01635581.2011. 523503

Rajendran, P., Delage, B., Dashwood, W. M., Yu, T. W., Wuth, B., Williams, D. E., et al. (2011). Histone deacetylase turnover and recovery in sulforaphane-treated colon cancer cells: competing actions of 14-3-3 and Pin1 in HDAC3/SMRT corepressor complex dissociation/reassembly. Mol. Cancer 10:68. doi: 10.1186/ 1476-4598-10-68

Rezk, N. A., Mohamed, R. H., Alnemr, A. A., and Harira, M. (2018). Promoter methylation of RASSF1A gene in egyptian patients with ovarian cancer. Appl. Biochem. Biotechnol. 185, 153-162. doi: 10.1007/s12010-017-2648-4

Royston, K. J., Udayakumar, N., Lewis, K., and Tollefsbol, T. O. (2017). A novel combination of withaferin a and sulforaphane inhibits epigenetic machinery, cellular viability and induces apoptosis of breast cancer cells. Int. J. Mol. Sci. 18:1092. doi: 10.3390/ijms18051092

Saxena, M., Saxena, J., Nema, R., Singh, D., and Gupta, A. (2013). Phytochemistry of medicinal plants. J. Pharm. Phytochem. 1, 168-182. doi: 10.3390/ ijms18051092

Shankar, E., Kanwal, R., Candamo, M., and Gupta, S. (2016). "Dietary phytochemicals as epigenetic modifiers in cancer: Promise and challenges," in Seminars in Cancer Biology, Vol. 40, (Cambridge, MA: Academic Press), 82-99. doi: 10.1016/j.semcancer.2016.04.002

Shanmugam, M. K., Arfuso, F., Arumugam, S., Chinnathambi, A., Jinsong, B., Warrier, S., et al. (2018). Role of novel histone modifications in cancer. Oncotarget 9:11414. doi: 10.18632/oncotarget.23356

Sharma, S., Kelly, T. K., and Jones, P. A. (2010). Epigenetics in cancer. Carcinogenesis 31, 27-36. doi: 10.1093/carcin/bgp220

Sharma, V., Kumar, L., Mohanty, S. K., Maikhuri, J. P., Rajender, S., and Gupta, G. (2016). Sensitization of androgen refractory prostate cancer cells to anti-androgens through re-expression of epigenetically repressed androgen receptor-synergistic action of quercetin and curcumin. Mol. Cell. Endocrinol. 431, 12-23. doi: 10.1016/j.mce.2016.04.024

Shi, L., Sun, L., Li, Q., Liang, J., Yu, W., Yi, X., et al. (2011). Histone demethylase JMJD2B coordinates $\mathrm{H} 3 \mathrm{~K} 4 / \mathrm{H} 3 \mathrm{~K} 9$ methylation and promotes hormonally 
responsive breast carcinogenesis. Proc. Natl. Acad. Sci. U.S.A. 108, 7541-7546. doi: $10.1073 /$ pnas. 1017374108

Shukla, S., Meeran, S. M., and Katiyar, S. K. (2014). Epigenetic regulation by selected dietary phytochemicals in cancer chemoprevention. Cancer Lett. 355, 9-17. doi: 10.1016/j.canlet.2014.09.017

Singh, C. K., George, J., and Ahmad, N. (2013). Resveratrol-based combinatorial strategies for cancer management. Ann. N. Y. Acad. Sci. 1290, 113-121. doi: $10.1111 /$ nyas. 12160

Sirerol, J. A., Rodríguez, M. L., Mena, S., Asensi, M. A., Estrela, J. M., and Ortega, A. L. (2016). Role of natural stilbenes in the prevention of cancer. Oxid. Med. Cell. Longev. 2016: 3128951. doi: 10.1155/2016/3128951

Smith, B. C., and Denu, J. M. (2009). Chemical mechanisms of histone lysine and arginine modifications. Biochim. Biophys. Acta Gene Regul. Mech. 1789, 45-57. doi: 10.1016/j.bbagrm.2008.06.005

Sundaram, M. K., Ansari, M. Z., Mutery, A. A., Ashraf, M., Nasab, R., Rai, S., et al. (2017). Genistein induces alterations of epigenetic modulatory signatures in human cervical cancer cells. Anticancer Agents Med. Chem. 18, 412-421. doi: 10.2174/1871520617666170918142114

Tan, S., Wang, C., Lu, C., Zhao, B., Cui, Y., Shi, X., et al. (2009). Quercetin is able to demethylate the p16INK4a gene promoter. Chemotherapy 55, 6-10. doi: 10.1159/000166383

Thakur, V. S., Deb, G., Babcook, M. A., and Gupta, S. (2014). Plant phytochemicals as epigenetic modulators: role in cancer chemoprevention. AAPS J. 16, 151-163. doi: 10.1208/s12248-013-9548-5

Thakur, V. S., Gupta, K., and Gupta, S. (2011). Green tea polyphenols causes cell cycle arrest and apoptosis in prostate cancer cells by suppressing class I histone deacetylases. Carcinogenesis 33, 377-384. doi: 10.1093/carcin/bgr277

Tian, F. M., Zhong, C. Y., Wang, X. N., and Meng, Y. (2017). PDE3A is hypermethylated in cisplatin resistant non-small cell lung cancer cells and is a modulator of chemotherapy response. Eur. Rev. Med. Pharmacol. Sci. 21, 2635-2641.

Tortorella, S. M., Royce, S. G., Licciardi, P. V., and Karagiannis, T. C. (2015). Dietary sulforaphane in cancer chemoprevention: the role of epigenetic regulation and HDAC inhibition. Antioxid. Redox Signal. 22, 1382-1424. doi: 10.1089/ars.2014.6097

Tsao, R. (2010). Chemistry and biochemistry of dietary polyphenols. Nutrients 2, 1231-1246. doi: 10.3390/nu2121231

Tseng, T. H., Chien, M. H., Lin, W. L., Wen, Y. C., Chow, J. M., Chen, C. K., et al. (2017). Inhibition of MDA-MB-231 breast cancer cell proliferation and tumor growth by apigenin through induction of G2/M arrest and histone $\mathrm{H} 3$ acetylation-mediated p21WAF1/CIP1 expression. Environ. Toxicol. 32, 434444. doi: $10.1002 /$ tox. 22247

Vardi, A., Bosviel, R., Rabiau, N., Adjakly, M., Satih, S., Dechelotte, P., et al. (2010). Soy phytoestrogens modify DNA methylation of GSTP1, RASSF1A, EPH2 and BRCA1 promoter in prostate cancer cells. In Vivo 24, 393-400.

Verma, M., and Srivastava, S. (2002). Epigenetics in cancer: implications for early detection and prevention. Lancet Oncol. 3, 755-763. doi: 10.1016/S14702045(02)00932-4

Wang, P., Henning, S. M., Heber, D., and Vadgama, J. V. (2015). Sensitization to docetaxel in prostate cancer cells by green tea and quercetin. J. Nutr. Biochem. 26, 408-415. doi: 10.1016/j.jnutbio.2014.11.017

Wang, Z., and Chen, H. (2010). Genistein increases gene expression by demethylation of WNT5a promoter in colon cancer cell line SW1116. Anticancer Res. 30, 4537-4545.

Wong, C. P., Hsu, A., Buchanan, A., Palomera-Sanchez, Z., Beaver, L. M., Houseman, E. A., et al. (2014). Effects of sulforaphane and 3, 3'diindolylmethane on genome-wide promoter methylation in normal prostate epithelial cells and prostate cancer cells. PLoS One 9:e86787. doi: 10.1371/ journal.pone.0086787

Wu, B., Yao, X., Nie, X., and Xu, R. (2013). Epigenetic reactivation of RANK in glioblastoma cells by curcumin: involvement of STAT3 inhibition. DNA Cell Biol. 32, 292-297. doi: 10.1089/dna.2013.2042

Xiao, X., Shi, D., Liu, L., Wang, J., Xie, X., Kang, T., et al. (2011). Quercetin suppresses cyclooxygenase-2 expression and angiogenesis through inactivation of P300 signaling. PLoS One 6:e22934. doi: 10.1371/journal.pone.0022934

Yadav, P., Masroor, M., Nandi, K., Kaza, R. C. M., Jain, S. K., Khurana, N., et al. (2018). Promoter Methylation of BRCA1, DAPK1 and RASSF1A is associated with increased mortality among Indian women with breast cancer. Asian Pac. J. Cancer Prev. 19:443. doi: 10.22034/APJCP.2018. 19.2.443

Yang, W. T., and Zheng, P. S. (2014). Promoter hypermethylation of KLF4 inactivates its tumor suppressor function in cervical carcinogenesis. PLoS One 9:e88827. doi: 10.1371/journal.pone.0088827

Yu, J., Peng, Y., Wu, L. C., Xie, Z., Deng, Y., Hughes, T., et al. (2013). Curcumin down-regulates DNA methyltransferase 1 and plays an anti-leukemic role in acute myeloid leukemia. PLoS One 8:e55934. doi: 10.1371/journal.pone. 0055934

Zadi Heydarabad, M., Nikasa, M., Vatanmakanian, M., Azimi, A., and Farshdousti Hagh, M. (2018). Regulatory effect of resveratrol and prednisolone on MDR1 gene expression in acute lymphoblastic leukemia cell line (CCRF-CEM): an epigenetic perspective. J. Cell. Biochem. 119, 4890-4896. doi: 10.1002/jcb. 26709

Zaidi, S. K., Van Wijnen, A. J., Lian, J. B., Stein, J. L., and Stein, G. S. (2013). Targeting deregulated epigenetic control in cancer. J. Cell. Physiol. 228, 2103-2108. doi: 10.1002/jcp. 24387

Zamora-Ros, R., Béraud, V., Franceschi, S., Cayssials, V., Tsilidis, K. K., and Boutron-Ruault, M. C. (2018). Consumption of fruits, vegetables and fruit juices and differentiated thyroid carcinoma risk in the European Prospective Investigation into Cancer and Nutrition (EPIC) study. Int. J. Cancer 142, 449-459. doi: 10.1002/ijc.30880

Zhang, C., Su, Z. Y., Khor, T. O., Shu, L., and Kong, A. N. T. (2013). Sulforaphane enhances Nrf2 expression in prostate cancer TRAMP C1 cells through epigenetic regulation. Biochem. Pharmacol. 85, 1398-1404. doi: 10.1016/j.bcp. 2013.02.010

Zhang, T., Cooper, S., and Brockdorff, N. (2015). The interplay of histone modifications-writers that read. EMBO Rep. 16, 1467-1481. doi: 10.15252/ embr.201540945

Zhang, W., Barger, C. J., Link, P. A., Mhawech-Fauceglia, P., Miller, A., Akers, S. N., et al. (2015). DNA hypomethylation-mediated activation of Cancer/Testis Antigen 45 (CT45) genes is associated with disease progression and reduced survival in epithelial ovarian cancer. Epigenetics 10, 736-748. doi: 10.1080/ 15592294.2015.1062206

Zhang, Y., Li, Q., and Chen, H. (2013). DNA methylation and histone modifications of Wnt genes by genistein during colon cancer development. Carcinogenesis 34, 1756-1763. doi: 10.1093/carcin/bgt129

Zhao, W., Zhou, X., Qi, G., and Guo, Y. (2018). Curcumin suppressed the prostate cancer by inhibiting JNK pathways via epigenetic regulation. J. Biochem. Mol. Toxicol. 32:e22049. doi: 10.1002/jbt.22049

Zheng, N. G., Wang, J. L., Yang, S. L., and Wu, J. L. (2014). Aberrant epigenetic alteration in Eca9706 cells modulated by nanoliposomal quercetin combined with butyrate mediated via epigenetic-NF-кB signaling. Asian Pac. J. Cancer Prev. 15, 4539-4543. doi: 10.7314/APJCP.2014.15.11.4539

Zhou, Y., Zheng, J., Li, Y., Xu, D. P., Li, S., Chen, Y. M., et al. (2016). Natural polyphenols for prevention and treatment of cancer. Nutrients 8:515. doi: 10 . 3390/nu8080515

Zhu, W., Qin, W., Zhang, K., Rottinghaus, G. E., Chen, Y. C., Kliethermes, B., et al. (2012). Trans-resveratrol alters mammary promoter hypermethylation in women at increased risk for breast cancer. Nutr. Cancer 64, 393-400. doi: 10.1080/01635581.2012.654926

Zhu, Y., Zhang, J. J., Zhu, R., Zhu, Y., Liang, W. B., and Gao, W. T. (2011). The increase in the expression and hypomethylation of MUC4 gene with the progression of pancreatic ductal adenocarcinoma. Med. Oncol. 28, 175-184. doi: $10.1007 / \mathrm{s} 12032-010-9683-0$

Conflict of Interest Statement: The authors declare that the research was conducted in the absence of any commercial or financial relationships that could be construed as a potential conflict of interest.

Copyright (c) 2019 Carlos-Reyes, López-González, Meneses-Flores, Gallardo-Rincón, Ruíz-García, Marchat, Astudillo-de la Vega, Hernández de la Cruz and LópezCamarillo. This is an open-access article distributed under the terms of the Creative Commons Attribution License (CC BY). The use, distribution or reproduction in other forums is permitted, provided the original author(s) and the copyright owner(s) are credited and that the original publication in this journal is cited, in accordance with accepted academic practice. No use, distribution or reproduction is permitted which does not comply with these terms. 